ЛАПШИНАркадий Олегович - кандидат историческихнаук, главный редактор журнала «Власть», член президиума Академии политической науки (117218, Россия, г. Москва, ул. Кржижановского, д. 24/35, кopn. 5; ark2050@yandex.ru)

\title{
КУЛЬТУРНАЯ ПОЛИТИКА И НАЦИОНАЛЬНО- ГОСУДАРСТВЕННЫЙ СУВЕРЕНИТЕТ В УСЛОВИЯХ НОВОЙ НОРМАЛЬНОСТИ
}

\begin{abstract}
Аннотация. Автор предлагает краткий анализ тематики круглого стола, организованного Академией политических наук, Школой молодого этнополитолога в Республике Башкортостан и журналом «Власть» «Культурная политика и национально-государственный суверенитет» и акцентирует внимание на ключевых проблемах так называемой новой мировой нормальности, обострившихся в связи с пандемией COVID-19. В статье поставлен ряд вопросов, требующих дальнейшего обсуждения на страницах журнала.
\end{abstract}

Ключевые слова: глобализация, сетевые коммуникации, цифровые структуры, пандемия, культурная политика

K руглый стол, темы которого мы предлагаем вниманию нашего читателя, проходил в условиях пандемии, которая явилась мощным катализатором и одновременно триггером накопившихся (как правило, негативных) тенденций и процессов. Они коснулись каждого из нас, проявились и во внутренней политике государств, и в сфере международных отношений. Тем не менее поднятые авторами проблемы не только сохранили свою актуальность, но стали значительно острее. Как в условиях этой новой нормальности, а если говорить совсем откровенно, ненормальности, взаимодействуют традиционные институты власти и получившие значительное увеличение своего влияния новейшие субъекты коммуникаций - всевозможные сетевые платформы и иные цифровые структуры? Каковы векторы эволюции этих процессов? Насколько глубоко они проникли в ткань нашей жизни, видоизменяя традиционные ее уклады? Наконец, как влияет эта новая реальность на культурную политику государства и его суверенитет? Весьма показателен пример, который я взял из экспертной записки Счетной палаты России ${ }^{1}$. По данным аудиторов, суммарные расходы на $I T$-процессы в 2019 г. (до пандемии) в Минобрнауки и Минпросвещения достигли 1,6 млрд руб., что в 11-12 раз выше, чем средние ежегодные траты ведомств в прошлом. На что ушли деньги, эксперты из Счетной палаты не знают.

Известный российский культуролог профессор Андрей Пелипенко считал, что Интернет является одним из ключевых системных феноменов культурноантропологической эволюции современного человека. Добавим сюда новейшие сетевые коммуникационные связи и отношения, и получается действительно новая глобальная реальность, которая затрагивает все аспекты современной жизни. Как в этих условиях видоизменяется функционирование государственных институтов, всей партийно-политической системы, особенно в условиях пандемии, вызвавшей к жизни всевозможные ограничения и риски для жизни и здоровья людей? Хотелось бы надеяться, что намеченная с начала 2021 г. правительством М. Мишустина модернизация государственного управ-

1 IT-бюджеты федеральных органов власти: знание явное и скрытое: экспертная записка. M. 2020. № 2(2). $51 \mathrm{c}$. 
ления и сокращение государственного аппарата будут проходить не по лекалам и моделям недавней оптимизации медицины и образования. Печально, но в России оказалась самая низкая продолжительность здоровой жизни в Европе: она составляет 63,7 года (в Исландии - 71,9 года). Эта вопиющая ненормальность нашей реальности требует своего преодоления.

Сбережение народа в широком смысле, выход из демографического тупика является важнейшей задачей всех уровней власти. COVID-19 только предельно заострил эти фундаментальные проблемы.

Вывод о том, что пандемия способствовала превращению экономического кризиса в системный, стал общим местом. К сожалению, пока ни у кого нет понимания, как из него выходить. Англосаксонская модель глобализации, в основе которой лежат гиганты ТНК, просела и перестала быть единственным вектором развития. Общество массового потребления, которое она создала, привело к планетарным экологическим тупикам. Да и сама либеральная доктрина перестала быть похожей на себя, любимую.

В последнее время под влиянием COVID-19 в политике усилилась роль государств. Китай демонстрирует успехи в борьбе с пандемией, используя предельно жесткую централизацию и тотальную цифровизацию. В прошлое уходит приватность жизни и привычные формы общения. Но не возникает ли в связи с этим некая новая архаика при внешней цифровой оболочке? Цифровизация всегда ложится на социокультурную ткань общества, на его ментальные характеристики. Она не может быть некоей отдельной субстанцией. Если кто-то полагает, что это возможно, то он или лукавит, или не говорит о своих истинных замыслах. Возросшая роль $I T$-компаний в условиях пандемии трансформирует культурную политику государств, всех его институтов, радикально видоизменяет национально-государственный суверенитет. Вопрос, как это скажется на самой культуре, на ее гуманистической составляющей, наконец, на гуманитарных науках. Ведь культура в широком ее понимании - это не суррогаты массовых зрелищ, она представляет собой всю совокупность внебиологической активности человека.

Еще один принципиально важный момент. Пандемия многократно усугубила фактор неопределенности в индивидуальной и социальной жизни. При внешне возросшей информационной достаточности значительную часть информационных потоков образуют фейковые новости, откровенная дезинформация, попытки определенных кругов навязать клиповое, цифровое мышление. Весь этот негатив можно объединить понятием «информационная аномия». Необходимо продолжить изучение этого феномена, который проник внутрь государственных институтов и сопровождает каждого из нас в повседневной жизни. Пока серьезной вакцины против этого социального вируса не изобрели. Не следует забывать, что все это происходит в условиях информационной войны, которую Запад ведет против нас и наших союзников, прежде всего Китая.

Как России отстаивать в этих условиях свой национально-государственный суверенитет и идентичность? Почему, например, таким странам, как Китай и отчасти Япония, это сделать удается? В чем секрет их культурной политики?

Современные универсалистские, так называемые общечеловеческие ценности, формирующиеся на базе европоцентризма, способны нанести ущерб национальной идентичности, особенно если они сопрягаются с моделью массового потребления. Какова здесь роль экологического сознания и экополитики? Достаточны ли сегодня усилия, которые государства делают для перехода к модели устойчивого развития, или мы видим сплошь и рядом фраг- 
менты имитационных практик? Необходимо отвечать и на эти вопросы, пока не поздно.

И последнее. Вовлеченность детей с очень раннего возраста в Интернет и социальные сети меняет социально-психологический тип человека, его ментальность. Тем самым трансформируются экзистенциальные основания будущей человеческой культуры. Массовизация клипового сознания происходит повсеместно, создавая угрозы национальной безопасности, подрывая идентичность и видоизменяя национальный суверенитет. Какой должна быть в этих условиях культурная политика государства? Совершенно очевидно, что в условиях сегодняшней новой нормальности предложений, идущих от так называемой технонауки, явно недостаточно. Необходим междисциплинарный социогуманитарный анализ всех этих новых вызовов и рисков. Об этом неоднократно писал и говорил недавно ушедший от нас известный социолог и эколог профессор Олег Яницкий. Разумеется, глобализацию и цифровизацию жизни не остановить, да это и невозможно, но придать этим процессам некие новые составляющие, связанные с традиционными началами, прежде всего гуманистическими, необходимо. В противном случае мы рискуем оказаться в глобальной ненормальности для большинства.

Современный мир столкнулся с двуединым процессом: интеграция и автономизация происходят одновременно. COVID-19 только усилил динамику этих тенденций. Причем тренд на идентичность стал приобретать самые различные формы вплоть до радикального неопопулизма, этнизма и т.п. Все это крайне интересные объекты для научного анализа.

Я остановился только на некоторых аспектах поднятой на круглом столе темы. Думаю, что дальнейшее ее изучение продолжится, в т.ч. и на страницах нашего журнала.

Статья публикуется при поддержке Школы молодого этнополитолога в Республике Башкортостан (грант Фонда президентских грантов 19-2-022447).

LAPSHIN Arkadiy Olegovich, Cand.Sci. (Hist.), Editor-in-Chief of the Vlast' magazine, Member of the Presidium of the Academy of Political Science (bld. 5, 24/35 Krzhizhanovskogo St, Moscow, Russia, 117218; ark2050@yandex.ru)

\section{CULTURAL POLICY AND NATIONAL-STATE SOVEREIGNTY IN THE CONDITIONS OF THE NEW NORMALITY}

\footnotetext{
Abstract. The author offers a brief analysis of the topics of the Round table of the Academy of Political Science, of the School of Young Ethnopolitologist in Bashkortostan, of the Vlast magazine. He focuses on the key problems of the so-called new global normality, aggravated by the COVID-19 pandemic. The article raises a number of questions that require further discussion on the pages of the magazine.

Keywords: globalization, network communications, digital structures, pandemic, cultural policy
} 